\title{
Pengaruh Model Defoliasi Daun Jagung dan Jumlah Benih terhadap Hasil Jagung dan Kacang Nasi pada Sistem Tumpangsari Salome (Kearifan Lokal Timor)
}

\author{
Syprianus Ceunfin $^{\mathrm{a}}$, Maria Ursula Humoen ${ }^{\mathrm{a}}$, Sonya M. A. Boyfala ${ }^{\mathrm{a}}$, Apriana H. Seran ${ }^{\mathrm{a}}$, Adrianus Lelang ${ }^{\mathrm{a}}$ \\ ${ }^{a}$ Fakultas Pertanian, Universitas Timor, Kefamenanu, TTU - NTT, Indonesia.
}

\section{Article Info}

\section{Article history:}

Received 15 Juni 2017

Received in revised form 26 Maret 2018

Accepted 27 Maret 2018

\section{Keywords:}

Tumpangsari

Jagung

Kacang Nasi

LER

Salome

\begin{abstract}
Abstrak
Sistem tumpangsari yang dilakukan di pulau Timor khususnya Kabupaten Timor Tengah Utara (TTU) masih sangat tradisional yaitu dengan menanam beberapa jenis tanaman yang berbeda spesies dalam lubang tanam yang sama. Sistem ini biasanya disebut dengan Salome atau satu lubang rame-rame. Sistem tumpangsari salome tentunya memiliki kelemahan yaitu terjadi persaingan secara vertikal maupun secara horizontal. Penelitian ini bertujuan untuk mengetahui pengaruh model defoliasi dan jumlah benih terhadap hasil jagung dan kacang nasi serta untuk mengetahui Land Equivalend Racio (LER) dalam sistem tumpangsari salome. Rancangan yang digunakan dalam penelitian ini adalah Rancangan Acak Kelompok (RAK) factorial 6 x 4 + monokultur yang diulang 3 kali. Faktor pertama adalah model defoliasi daun jagung, Tanpa defoliasi, defoliasi batang atas 50\% dari tongkol, defoliasi batang atas $100 \%$ dari tongkol, defoliasi daun jagung dengan hanya meninggalkan tulang daun $100 \%$ dari pangkal hingga daun bendera, defoliasi daun jagung dengan han ya meninggalkan tulang daun dari daun bendera hingga tongkol, defoliasi daun jagung dengan hanya meninggalkan tulang daun dari daun pangkal hingga tongkol. Faktor kedua adalah perbandingan jumlah benih jagung umur genjah kultivar lokal timor dan benih kacang nasi tipe tegak, satu jagung satu kacang, satu jagung dua kacang, dua jagung satu kacang, dua jagung dua kacang. Hasil penelitian menunjukkan bahwa model defoliasi daun jagung dan jumlah benih mempengaruhi hasil jagung secara signifikan tetapi tidak berpengaruh terhadap hasil kacang nasi dan tumpangsari salome menghasilkan nilai total LER>1. @2018 dipublikasikan oleh Savana Cendana.
\end{abstract}

\section{Pendahuluan}

Pulau Timor merupakan wilayah semiarid dengan jumlah curah hujan yang tidak menentu pada setiap siklus tahunannya. Kebihan air terjadi pada musim hujan serta mengalami kekurangan air hujan pada musim kemarau. Air hujan umumnya merupakan sumber irigasi bagi tanaman di wilayah Timor terutama pada lahan kering. Kelimpahan air hujan terjadi antara bulan November-Maret atau 5 bulan, sedangkan kekurangan air atau musim kering dimulai dari bulan April-Oktober atau setara dengan 7 bulan.

Penanggulangan terhadap kekurangan air diakhir musim hujan, masyarakat di pulau Timor terbiasa dengan melakukan sistem tanam tumpangsari. Suchri (2010), Tumpangsari merupakan model penanaman dalam sebidang lahan, dimana dua atau lebih spesies tanaman yang ditanaman dalam waktu bersamaan, Permanasari dan Kastono (2012) atau waktu berbeda dengan penanaman berselang-seling dan jarak tanam teratur pada sebidang tanah yang sama Selanjutnya Suchri (2010), menyatakan bahwa sistem tumpangsari memiliki keuntungan antaralain mengurangi resiko gagal panen, memperbaiki kesuburan tanah, menekan pertumbuhan gulma, hama dan penyakit serta meningkatkan pendapatan petani, Permanasari dan Kastono (2012), hemat dalam pemakaian sarana produksi dan mampu meningkatkan efisiensi penggunaan lahan. Turmud (2002), menyatakan sistem tumpangsari lebih menguntungkan dibanding sistem monokultur karena produksivitas lahan menjadi lebih tinggi, jenis komoditas yang dihasilkan beragam, hemat dalam pemakaian sarana produksi dan resiko kegagalan dapat diperkecil.

Sistem tumpangsari yang dilakukan di pulau Timor khususnya Kabupaten Timor Tengah Utara (TTU) masih sangat tradisional yaitu dengan menanam beberapa jenis tanaman yang berbeda spesies dalam lubang tanam yang sama. Sistem ini biasanya disebut dengan Salome atau satu lobang rame-rame. Sebutan lobang bagi orang Timor dalam hal ini sejajar dengan lubang tanam. Menuru Levis et al., (2017) Salah satu bentuk kearifan lokal dalam meningkatkan ketahanan pangan orang Timor adalah sistem pengelolaan tanah dan tanaman yang mana beberapa jenis tanaman pangan ditanam secara bersamaan waktu dalam satu lubang tanam yang sama (salome). Sistem tumpangsari salome dilakukan pada musim hujan untuk memanfaatkan curah hujan yang terjadi pada bulan November-Maret dan mulai kekurang air diawal musim kering. Sistem tumpangsari salome tentunya memiliki kelemahan yaitu terjadi persaingan secara vertical maupun secara horizontal. Untuk menghindari kelemahan dari sistem tumpangsari salome ada berbagai teknologi yang bisa digunakan.

Teknologi sederhana yang bisa diterapkan adalah dengan melakukan defoliasi daun untuk meningkatkan produksi tanaman baik tanaman utama maupun tanaman yang ditumpangsarikan. Hopkins (1995), Defoliasi adalah pemangkasan ujung batang. Defoliasi dimaksudkan untuk mengurangi saling menaungi antar tanaman maupun antara daun dalam tanaman yang bertujuan untuk meningkatkan penumpukan hasil fotosintesis pada biji tanaman. Indradewa et.al., (2015) menyatakan bahwa Konversi bahan kering dar pemendekan batang diperhitungkan maksimal dapat meningkatkan hasil sebesa $4,15 \%$ pada tanaman yang $50 \%$ lebih pendek dari tanaman normal. Surtinah (2005), menyatakan Produksi biji pada tanaman yang dipangkas $1 / 2$ bagian daun di atas tongkol lebih tinggi dibandingkan tanaman yang tidak dipangkas dengan pemberian pupuk Urea yang sama. Selanjutnya Suchri (2010), menyatakan defoliasi daun jagung berpengaruh nyata terhadap pertumbuhan, hasil dan komponen hasil tanaman kacang tanah dalam tumpangsari.

Tumpangsari akan menguntungkan bila populasi tanaman dalam sistem pertanaman diperhatikan. Banyak penelitian telah dilakukan di wilayah-wilayah semiarid yang menyatakan bahwa sistem tumpangsari menguntungkan dengan berbagai populasi dan berbagai tanaman. pengaturan penanaman 2 baris sorgum:1 baris copea menunjukkan LER, nilai indeks kompetisi, lebih tingg dibandingkan dengan pengaturan penanaman lainnya pada tumpangsari dan tanaman tunggal (Oseni, 2010). Takim (2012), bahwa proporsi campuran 50 maize: 50 kacang tunggak dalam barisan tumpangsari, memberikan hasil biji yang lebih baik dalam efisiensi penggunaan lahan dengan nilai kehilangan hasi aktual terendah $23 \%$. Hasil penelitian lain menunjukkan bahwa tumpangsari dengan proporsi $50 \%$ wijen $+50 \%$ kacang buncis memberikan nilai LER $>1$ pada sistem tumpangsari campuran (Nurbakhsh et. al., 2013).

Permasalahannya adalah belum diketahui model defoliasi dan jumlah benih jagung dan kacang nasi dalam sistem tumpangsari salome sehingga penelitian in bertujuan untuk mengetahui pengaruh model defoliasi dan jumlah benih serta untuk mengetahui Land Equivalend Racio (LER) dalam sistem tumpangsari salome.

\section{Metode}

Penelitian ini dilaksanakan di lahan percobaan, Fakultas Pertanian, Universitas Timor. Pada tanggal 27 September 2016 sampai dengan bulan Januaari 2017. Rancangan yang digunakan dalam penelitian ini adalah Rancangan Acak Kelompok (RAK) factorial 6 x 4 + kontrol model defoliasi dan monokultur yang diulang 3 kali. Faktor pertama adalah model defoliasi daun jagung, Tanpa defoliasi (D0), defoliasi batang atas 50\% dari tonglol (D1), defoliasi batang atas $100 \%$ dari tongkol (D2), defoliasi daun jagung dengan hanya meninggalkan tulang daun $100 \%$ dari pangkal hingga daun bendera (D3), defoliasi daun jagung dengan hanya meninggalkan tulang daun dari dari daun bendera hingga tongkol (D4), defoliasi daun jagung dengan hanya meninggalkan tulang daun dari daun pangkal hingga tongkol (D5). Perlakuan D1 dan D2 merupakan metode pemangkasan batang dan perlakuan D3, D4 dan D5 merupakan metode guratan daun sebagai adaptasi serangan hama belalang kembara yang menyerang tanaman jagung

Faktor kedua adalah perbandingan jumlah benih jagung umur genjah kultivar lokal timor dan benih kacang nasi tipe tegak, satu jagung satu kacang (C1), satu jagung dua kacang (C2), dua jagung satu kacang (C3), dua jagung dua kacang (C4).

Penelitian ini menggunakan polybag dengan media tanam campuran tanah dan pupuk kandang sapi. Benih yang digunakan adalah benih jagung (Zea mays L.) kuning lokal kultivar umur genjah dan kacang nasi (Vigna umbellate (Thunb.)) Pupuk kandang sapi digunakan sebagai pupuk dasar, yang di campurkan dengan media tanah sebelum penanaman dan pemupukan susulan menggunakan pupuk guano sebanyak $20 \mathrm{~g} /$ polybag setelah tanaman berbunga. Defoliasi daun jagung dilakukan setelah terjadi penyerbukan yang ditandai dengan bunga betina terlihat kering, sesuai dengan perlakuan yang telah ditentukan yaitu tanpa defoliasi (D0), defoliasi batang atas $50 \%$ dari tongko (D1), defoliasi batang atas $100 \%$ dari tongkol (D2), defoliasi daun jagung dengan hanya meninggalkan tulang daun $100 \%$ dari pangkal sampai daun bendera (D3), defoliasi daun jagung dengan hanya meninggalkan tulang daun dari daun bendera hingga tongkol (D4), defoliasi daun jagung dengan hanya meninggalkan tulang daun dari pangkal hingga tongkol (D5). Panen jagung dilakukan setelah klobot jagung sepenuhnya kering dan polong kacang dipanen setelah terlihat kering yang ditandai dengan perpubahan warna polong dari hijau menjadi coklat. Parameter yang diamati dalam penelitian ini adalah berat kering oven jagung per tanaman, berat kering oven kacang nasi per tanaman dan Land Equivalend Racio (LER)

Analisa data dilakukan dengan menggunakan sidik ragam (Anova) Rancangan Acak Kelompok-Faktorial (RAK-Faktorial), rata-rata perlakuan selanjutnya diuji dengan menggunakan Duncan Multiple Range Test (DMRT) dengan tingkat signifikan 5\% menggunakan program SAS 9.1.

\section{Hasil dan Pembahasan}

Hasil penelitian menunjukkan bahwa tidak terjadi interaksi antara perlakuan defoliasi daun jagung dan jumlah benih dalam tumpangsari salome terhadap 
parameter perlakuan berat kering oven biji jagung/tanaman, berat kering oven biji kacang/tanaman dan Land Equivalend Racio (LER).

\subsection{Berat Biji Jagung}

Terjadi beda nyata pada aras perlakuan defoliasi daun jagung terhadap parameter pengamatan berat kering oven biji jagung per tanaman, berat kering oven biji jagung per pot, dan berat 100 biji. Perlakuan tanpa defoliasi daun jagung menghasilkan berat biji jagung paling tinggi yang berbeda sangat nyata dengan perlakuan defoliasi daun jagung dengan hanya meninggalkan tulang daun $100 \%$ dari pangkal hingga daun bendera (D3) dapat dilihat pada Gambar 1.

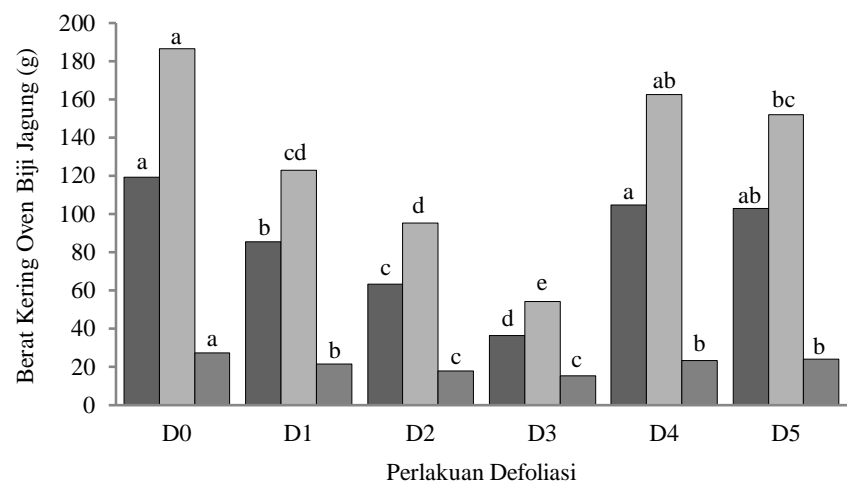

$\square$ Berat kering oven biji per tanaman $\square$ Berat kering oven biji per pot $\square$ Berat 100 biji

Gambar 1. Tanpa defoliasi (D0), defoliasi batang atas $50 \%$ dari tongkol (D1), defoliasi batang atas $100 \%$ dari tongkol (D2), defoliasi daun jagung dengan hanya meninggalkan tulang daun $100 \%$ dari pangkal sampai daun bendera (D3), defoliasi daun jagung dengan hanya meninggalkan tulang daun dari daun bendera hingga tongkol (D4), defoliasi daun jagung dengan hanya meninggalkan tulang daun dari pangkal hingga tongkol (D5) ); huruf sama yang terletak diatas diagram dengan warna yang sama tidak berbeda nyata pada uji taraf nyata DMRT $\alpha 0,05$.

Terjadi beda nyata pada aras perlakuan jumlah benih terhadap parameter pengamatan berat kering oven biji jagung per tanaman dan berat kering oven biji jagung per pot, sedangkan berat 100 biji tidak terjadi beda nyata. Perlakuan jumlah benih jagung satu ( $\mathrm{C} 1$ dan $\mathrm{C} 2)$ menghasilkan berat kering oven per tanaman paling tinggi yang berdeda sangat nyata dengan perlakuan jumlah benih jagung 2 biji (C3 dan $\mathrm{C} 4$ ) dan monokultur, sedangkan pada pengamatan berat biji per pot menghasilkan berat biji paling tinggi pada perlakuan jumlah benih jagung 2 (C3, C4 dan monokultur) yang berbeda nyata dengan perlakuan jumlah benih jagung 1 (C1 dan $\mathrm{C} 2)$, dapat dilihat pada Gambar 2.

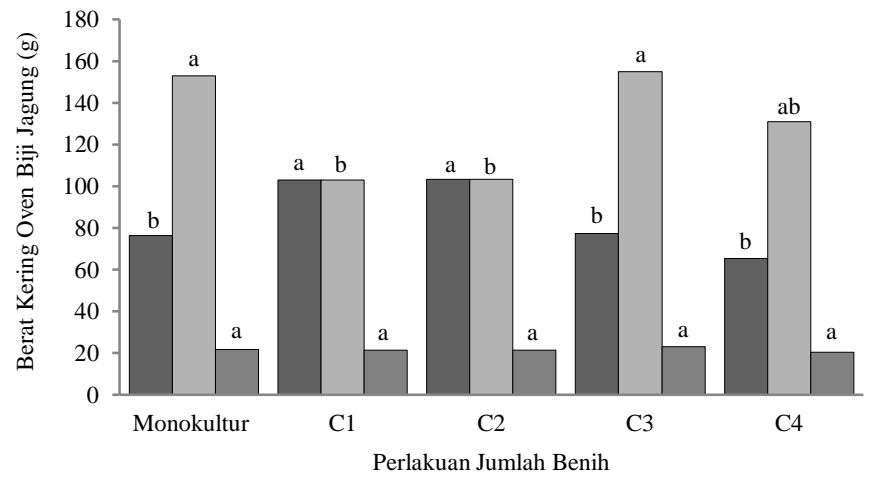

$\square$ Berat kering oven biji per tanaman $\square$ Berat kering oven biji per pot $\square$ Berat 100 biji

Gambar 2. Monokultura, Jumlah benih jagung satu kacang satu (C1), jumlah benih jagung satu kacang dua (C2), jumlah benih jagung dua kacang satu (C3), jumlah benih jagung dua kacang dua (C4) ); huruf sama yang terletak diatas diagram dengan warna yang sama tidak berbeda nyata pada uji taraf nyata DMRT $\alpha 0,05$.

\subsection{Berat kering oven Biji Kacang}

Perlakuan defoliasi daun jagung maupun perlakuan jumlah benih jagung dan kacang nasi menunjukkan tidak berbeda nyata terhadap parameter pengamatan berat kering oven biji kacang nasi per tanaman, berat kering oven kacang nasi per pot dan berat 100 biji (Gambar 3. dan Gambar 4.).

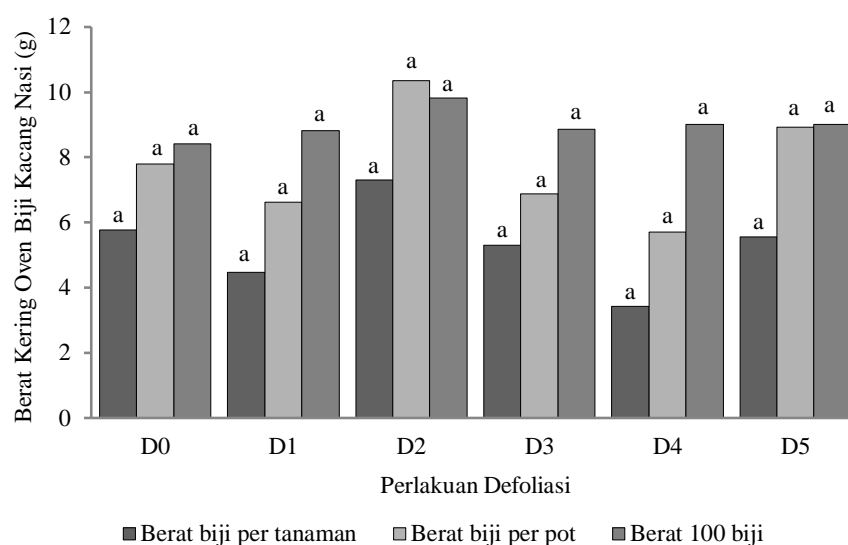

Gambar 3. Tanpa defoliasi (D0), defoliasi batang atas $50 \%$ dari tongkol (D1), defoliasi batang atas $100 \%$ dari tongkol (D2), defoliasi daun jagung dengan hanya meninggalkan tulang daun $100 \%$ dari pangkal sampai daun bendera (D3), defoliasi daun jagung dengan hanya meninggalkan tulang daun dari daun bendera hingga tongkol (D4), defoliasi daun jagung dengan hanya meninggalkan tulang daun dari pangkal hingga tongkol (D5) ); huruf sama yang terletak diatas diagram dengan warna yang sama tidak berbeda nyata pada uji taraf nyata DMRT $\alpha 0,05$.

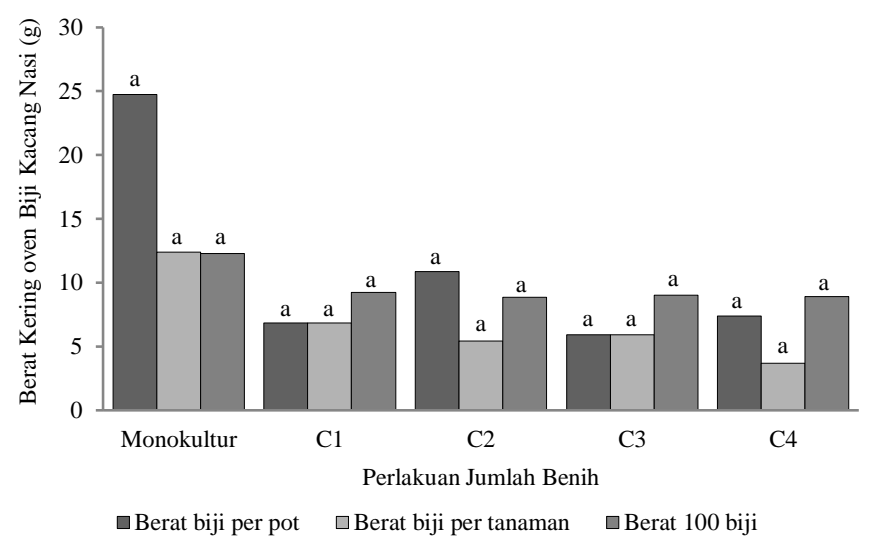

Gambar 4. Monokultura, Jumlah benih jagung satu kacang satu (C1), jumlah benih jagung satu kacang dua $(\mathrm{C} 2)$, jumlah benih jagung dua kacang satu (C3), jumlah benih jagung dua kacang dua (C4) ); huruf sama yang terletak diatas diagram dengan warna yang sama tidak berbeda nyata pada uji taraf nyata DMRT $\alpha 0,05$.

\subsection{Land Equivalend Racio (LER)}

Terjadi beda nyata pada aras perlakuan defoliasi daun jagung terhadap parameter LER jagung dan total LER, sedangkan LER kacang nasi tidak terjadi beda nyata. Perlakuan defoliasi batang atas $100 \%$ dari tongkol (D2) menghasilkan nilai LER jagung paling tinggi yang berbeda nyata dengan perlakuan lainnya, sedangkan pada total LER menunjukkan bahwa perlakuan defoliasi batang atas $100 \%$ dari tongkol (D2) yang berbeda nyata dengan perlakuan defoliasi batang atas $50 \%$ dari tongkol (D1) tetapi tidak berbeda nyata perlakuan defoliasi lainnya, (Gambar 5.).

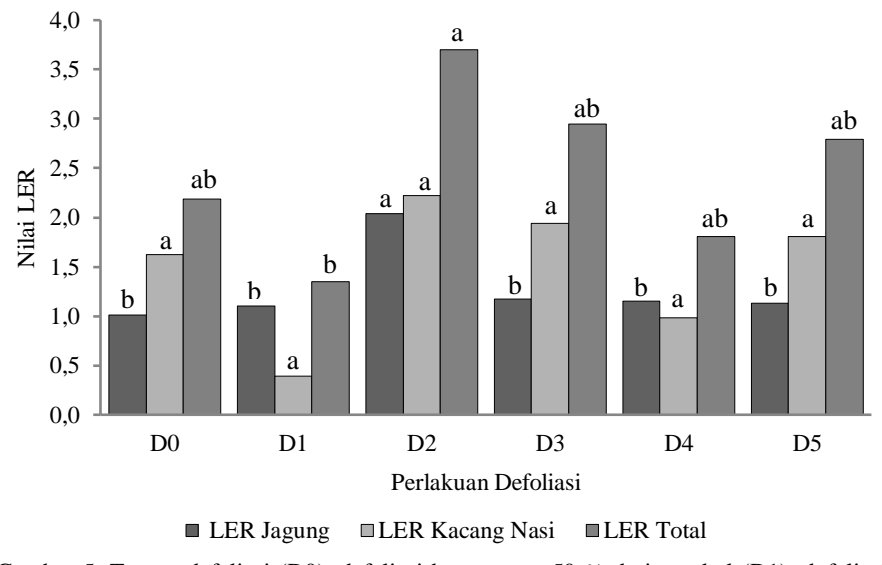

Gambar 5. Tanpa defoliasi (D0), defoliasi batang atas $50 \%$ dari tongkol (D1), defoliasi batang atas $100 \%$ dari tongkol (D2), defoliasi daun jagung dengan hanya meninggalkan tulang daun $100 \%$ dari pangkal sampai daun bendera (D3), defoliasi daun jagung dengan hanya meninggalkan tulang daun dari daun bendera hingga tongkol (D4), defoliasi daun jagung dengan hanya meninggalkan tulang daun dari pangkal hingga tongkol (D5); huruf sama yang terletak diatas diagram dengan warna yang sama tidak berbeda nyata pada uji taraf nyata DMRT $\alpha 0,05$. 
Terjadi beda nyata pada aras perlakuan jumlah benih terhadap parameter LER jagung, sedangkan LER kacang nasi dan total LER tidak terjadi beda nyata. Perlakuan jumlah benih jagung 1 dengan jumlah benih kacang nasi 1 dan 2 (C) dan C2) menghasilkan nilai LER lebih tinggi yang berbeda nyata dengan perlakuan jumlah benih jagung 2 dengan jumlah benih kacang nasi 2 (C4), Gambar 6 .

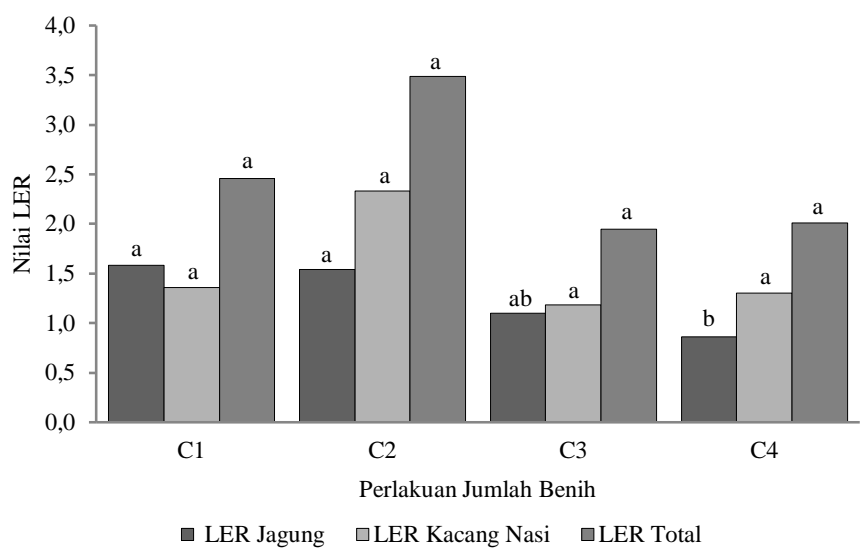

Gambar 6. Jumlah benih jagung satu kacang satu (C1), jumlah benih jagung satu kacang dua (C2), jumlah benih jagung dua kacang satu (C3), jumlah benih jagung dua kacang dua (C4) ); huruf sama yang terletak diatas diagram dengan warna yang sama tidak berbeda nyata pada uji taraf nyata DMRT $\alpha 0,05$.

\subsection{Pembahasan}

Tanaman jagung yang didefoliasi menghasilkan berat kering oven biji jagung lebih rendah dari tanaman jagung yang tidak didefoliasi. Hal ini disebkan oleh kegiatan defoliasi dilakukan pada saat blister, yang menyebabkan hasil fotosintesis pada tanaman jagung kemungkinan lebih banyak diarahkan untuk kegiatan penyembuhan luka saat defoliasi dari pada diarahkan untuk pengisian dan pembesaran biji jagung. Surtinah (2005) menyatakan bahwa tanaman yang dipangkas seluruh bagian daun pada saat pengisian biji tidak membagi hasil fotosintat untuk bagian tanaman di atas tongkol. Selain itu tanaman yang digurat seluruh helaian daun menyebabkan kehilangan organel-organel penting fotosintesis seperti klorofil dan stomata sehingga penumpukan hasil asimilasi pada biji kemungkinan berasal dari hasil respirasi dan atau organ tanaman yang bukan daun. Hal ini sesuai dengan pernyataan Surtinah (2005) bahwa asimilat yang digunakan untuk pengisian biji diperoleh dari tiga sumber utama yaitu fotosintesis daun saat sekarang, fotosintesis bagian lain yang bukan daun saat sekarang, dan remobilisasi hasil asimilasi yang disimpan dalam organ tanaman yang lain. Model pemangkasan daun jagung tidak mempengaruhi berat biji kacang nasi. Hal ini sesuai dengan pernyataan Permanasar dan Kastono (2012) bahwa Pemangkasan jagung tidak berpengaruh terhadap pertumbuhan kedelai.

Jumlah benih yang ditanaman dalam setiap perlakuan menunjukkan bahwa semakin banyak benih jagung menunjukkan bahwa hasil biji pertanaman rendah namun hasil biji per pot menjadi lebih tinggi. Hal ini berarti populasi tanaman jagung belum melebihi batas optimum karena hasil berat kering oven biji kacang nasi per tanaman maupun per pot dalam tumpangsari salome tidak berbeda nyata dengan tanaman kacang pada perlakuan monokultur.

Tumpangsari salome menunjukkan hasil menguntungkan baik pada perlakuan defoliasi maupun pada perlakuan jumlah benih. Hal ini dibuktikan dengan nilai total LER pada model defoliasi jagung maupun jumlah benih $>1$. Ini berarti model tumpangsari salome sangat cocok untuk diterapkan. Hal ini diperkuat oleh pernyataan Ceunfin et al. (2017) bahwa nilai LER dan ATER > 1 menggambarkan sistem tanam monokultur memerlukan lahan yang lebih luas dibandingkan dengan pola tumpangsari.

\section{Simpulan}

Tidak terjadi interaksi antara perlakuan model defoliasi dan jumlah benih terhadap hasil jagung dan kacang dalam tumpangsari salome, Model defoliasi dan jumlah benih mempengaruhi hasil jagung secara signifikan tetapi tidak berpengaruh terhadap hasil kacang nasi dan tumpangsari salome menghasilkan nilai total LER>1.

\section{Pustaka}

Beets W.C., 1982. Multiple Cropping and Tropical Farming System. Gower Publ Co. Chicago.

Ceunfin, S., Prajitno, D., Suryanto, P. \& Putra, E.T.S. 2017. Penilaian Kompetisi dan Keuntungan Hasil Tumpangsari Jagung Kedelai di Bawah Tegakan Kayu Putih. Savana Cendana, 2(01): 1-3.

Dima K.V., 2006. Competition Indices of Common Vetch and Seriel Intercrops in Two Seeding Racio. Elsevier, Cience Direct, Field Crops Recearch 100 (2007) 249-256.

Hopkins., 1995. Introduction to Plant Physiology. John Willey and Sons Inc, Singapore.
Indradewa D., Dody Kastono, dan Yusman Soraya., 2015. Kemungkinan Peningkatan Hasil Jagung Dengan Pemendekan Batang. Ilmu Pertanian Vol. 12 No.2, 2005: 117 - 124

Levis L. R., K. Sukesi, Sugiyanto and Y. Yuliati., 2017. Farmers Behaviour Regarding Food Security by Practicing The 'Salome' Farming System as Local Wisdom in West Timor, East Nusa Tenggara Province, Indonesia. Tropical and Subtropical Agroecosystems, 20 (2017): 231 - 236. Diakses 21 Februari 2018.

Mahapatra S.C., 2010. Study of Grass-Legume Intercropping System in Terms of Competition Indices and Monetary Advantage Index under Acid Lateritic Soil of India. American Journal of Experimental Agriculture 1(1): 1-6, 2011 Sciencedomain International .

Nurbakhsh.F, A. Koocheki, M. Nassiri Mahallati., 2013. Evaluation of Yield Yield Components and Different Intercropping Indices Ni Mixed and Row Intercropping of Sesame (Sesamumindicum L.) and Bean (Phaseolus vulgaris L.). International Journal of Agriculture and Crop Sciences. Available online at www.ijagcs.com IJACS/2013/5-17/1958-1965 ISSN 2227-670X (C)2013 IJACS Journal).

Oseni T. O., 2010. Evaluation of Sorghum-Cowpea Intercrop Productivity in Savanna Agro-ecology Using Competition Indices, Journal of Agricultural Science Vol. 2, No. 3; September 2010.

Permanasari I dan Dodi Kastono., 2012. Pertumbuhan Tumpangsari Jagung Dan Kedelai Pada Perbedaan Waktu Tanam Dan Pemangkasan Jagung. Jurnal Agroteknologi, Vol. 3 No. 1, Agustus 2012: 13-20.

Rezvani.F, Zaefarian, M. Aghaalikhani, H. Rahimian Mashhadi and E. Zand (2011) Investigation Corn and Soybean Intercropping Advantages in Competition with Redroot Pigweed and Jimsonweed M, World Academy of Science, Engineering and Technology Vol:5 2011-09-21.

Suchri Amin., 2010. Dampak Penataan Baris Tanam dan Defoliasi Daun Jagung terhadap hasil jagung (Varietas Tambin), pertumbuhan dan hasil kacang tanah (varietas Jerafah) Dalam Sistem Tumpangsari. Agrovigor Volume 3 No 1 ISSN 1979-5777.

Surtinah., 2005. Hubungan Pemangkasan Organ bagian Atas Tanaman Jagung (Zea mays, L) dan Dosis Urea terhadap Pengisian Biji. Jurnal Ilmiah Pertanian Vol. 1 No. 2 Februari 2005.

Takim F. O., 2012. Advantages of Maize-Cowpea Intercropping over Sole Cropping through Competition Indices. Journal of Agriculture and Biodiversity Research, ISSN 2277-0836; Volume 1, Issue 4, pp. 53-59; July 2012.

Turmudi E., 2002. Kajian Pertumbuhan Dan Hasil Tanaman Dalam Sistem Tumpangsari Jagung Dengan Empat Kultivar Kedelai Pada Berbagai Waktu Tanam. Jurnal Ilmu-Ilmu Pertanian Indonesia.Volume 4, No 2, hlm. 89-96. 